\title{
New Data on the Breeding Group of Cinereous Vulture in Altai Republic, Russia
}

\section{РЕЗУЛЬТАТЫ МОНИТОРИНГА ГНЕЗДОВОЙ ГРУППИРОВКИ ГРИФА НА АЛТАЕ, РОССИЯ}

\author{
Karyakin I.V. (Center of Field Studies, N. Novgorod, Russia) \\ Bachtin R.F., Vazhov S.V. (Shukshin Altai State Academy of Education, Biysk, Russia) \\ Barashkova A.N., Nikolenko E.G., Shnayder E.P. (Siberian Environmental Centre, \\ Novosibirsk, Russia) \\ Bekmansurov R.H. (Elabuga brunch of Kazan Federal University, Elabuga, Russia) \\ Карякин И.В. (Центр полевых исследований, Н. Новгород, Россия) \\ Бахтин Р.Ф., Важов С.В. (Алтайская государственная академия образования \\ им. В.М. Шукшина, Бийск, Россия) \\ Барашкова А.Н., Николенко Э.Г., Шнайдер Е.П. (МБОО «Сибирский экологический \\ центр», Новосибирск, Россия) \\ Бекмансуров Р.Х. (Елабужский институт Казанского Федерального университета, \\ Елабуга, Россия)
}

\section{Контакт: \\ Игорь Карякин \\ Центр полевых иссие- Аований \\ 603109, Россия, \\ Нижний Новгород, \\ ул. Нижегородская, 3-29 \\ тел.: +79625083037 \\ ikar_research@mail.ru \\ Роман Бахтин \\ тел.: +7905980 3139 \\ al.raptors@yandex.ru \\ Сергей Важов \\ тел.: +79635348107 \\ aquila-altai@mail.ru}

Анна Барашкова

yazula@yandex.ru

Эльвира Николенко elvira_nikolenko@mail.ru

Елена Шнайдер equ001@gmail.com

Ринур Бекмансуров rinur@yandex.ru

\section{Contact:}

Igor Karyakin

Center of Field Studies

Nizhegorodskaya str.,

3-29

Nizhniy Novgorod,

Russia, 603109

tel.: +7962 5083037

ikar_research@mail.ru

Roman Bachtin

tel.: +79059803139

al.raptors@yandex.ru
В республике А^тай, несмотря на частые встречи грисра (Aegypius monachus) в Юго-Восточном Алтае в начале XX столетия, П.П. Сушкин (1938) сомневаися в том, что гриср является гнезАяшимся зАесь виАом. Со статусом вероятно гнездяшегося в Аитае гриср приводится в сводке по птицам Советского Союза, со ссылкой на П.П. Сушкина (Аементьев, 1951). В конце XX столетия гриср наблюдаися наиболее часто в Юго-Восточном Алтае, в частности, на Сайлюгеме, Укоке и Южно-Чуйском хребте (Ирисова и мр., 1988; Ирисова, 1996; НейсрельАт, 1986), но вплоть $А$ конца XX столетия гнездование грифа на Алтае так и не было подтверждено, хотя и предполагалось на основании фактов гнездования вила в Туве и Монголии (Ирисова, 1996). Первые сведения о гнездовании грисра на Алтае были получены кишь в начале XXI столетия (Карякин и Ар., 2009а).

В 2003 г. грисы появились на гнезАовании на передовых скиадках южной перисерии Чуйской степи в низовьях Чаган-Бургазы (республика Алтай), гле построили свежее гнезАо, которое при проверке в июне оказалось пустым, но одна птица активно линяла на нём, а вторая находилась рялом. Аанный случай можно расценивать как первую попытку размножения грисра в республике (Карякин и Ар., 2009а). В 2000 г. зАесь грисов определённо не было, а на соседней полке этой же скамы размножамись мохноногие курганники (Buteo hemilasius). При
Observations of Cinereous Vultures (Aegypius monachus) occurred rather often through South-Eastern part of Altai in XX century. However, there was no evidence about breeding activities of this species in the region (Irisova, 1996). The first data about breeding population of Cinereous Vultures in Altai Republic, Russia were obtained only in the beginning of XXI century (Karyakin et al., 2009a).

In 2003 and 2008 we revealed several breeding attempts of solitary pairs which unfortunately were unsuccessful. The first positive breeding success was registered in 2006 in a colony of Cinereous Vultures that consists of three breeding pairs and inhabited the canyon of Chagan-Uzun river. In 2008-2011 two out of three pairs bred in neighbouring nests on the cliffs of the left side of the canyon with only $1.17 \mathrm{~km}$ distance between them. The third pair occupied a nest on the opposite side of the canyon, remote from two other nests on 0.95 and $1.16 \mathrm{~km}$. In 2013 only the third breeding pair was successful.

The pioneer pair of the colony that bred in one and the same nest from 2006, in 2013 has built a new nest in $290 \mathrm{~m}$ from the old one. Thus, this new nest now stands in 1.45 $\mathrm{km}$ and $1.37 \mathrm{~km}$ from the nests of two other pairs of the colony. In 2014 sucessful breeding was observed in both nests on the left side of the canyon.

In four years of data collecting (2008, 
Sergey Vazhov tel.: +79635348107 aquila-altai@mail.ru

Anna Barashkova yazula@yandex.ru

Elvira Nikolenko elvira_nikolenko@mail.ru

Elena Shnayder equ001@gmail.com

Rinur Bekmansurov rinur@yandex.ru проверке 11 июля 2008 г. Аанное гнезАо оказалось заброшенным, однако рялом была обнаружена ешё одна небрежная свежая постройка, скорее всего, 2007 г., и лишь подновлённая в текуший гоА. Птицы мержаиись рялом так же, как и в 2003 г., но не размножамись. В 2009 г. Аанный гнездовой участок прекратил своё сушествование и при последуюших наблюдениях в 20102014 гг. грисы с гнездовым поведением здесь не наблюдаиись.

Ешё один гнездовой участок грисров был выявлен в 2002 г. в Аолине Чаган-Узуна 1 июля 2002 г. в 7 км выше устья наблюдалась пара птиц, а 21 августа 2006 г. И. Гузеевым и Е. Кравченко здесь же обнаружено гнезАо грисра со слётком, который при беспокойстве покинул гнездо (Карякин и мр., 2009а).

В 2002 г. пара с явным гнездовым поведением наблюдалась севернее п. КошАгач на скионе Курайского хребта, однако Аанный участок позже не был обследован, поэтому гнездование подтвердить не удаヘось.

В сезон 2009 г. выявлен новый гнездовой участок грисов в Аолине р. Тархата - 8 июля на скалах левобережья мины, в 7 км выше выхода из ушелья в Чуйскую степь, обнаружено пустуюшее гнездо грисра, которое располагалось на вершине 10-метрового скаиьного уступа в 100 м нах рекой. В гнезде обнаружены лишь погадки и линные перья. Следов размножения в текуший сезон не выявлено, выстилка гнезда не обновлялась (Карякин и Ар., 2009б). При последуюших наблюдениях в 2010-2014 гг. гнездо оставалось пустуюшим, следов пребывания птиц на нём не зарегистрировано, хотя пара птиц отмечалась в 950 м от гнезда в 2011 г. (в данном районе одиночные грисы наблюдаются регулярно и многие ушелья на предмет возможного гнездования этого вида попросту не обследованы). Интересно то, что скала, на которой было обнаружено гнездо грисра, Аиительное время занимается Амя гнездования беркутом (Aquila chrysaetos), который успешно размножался на ней как раз в 2009-2013 гг. Ао 2009 г., вероятно, беркуты гнездились на 2,5 км, куда переместились в 2014 г.

В результате более или менее полного обследования ушелья низовий Чаган-Узуна было выявлено, что здесь сформировалась гнездовая группировка минимум из трёх пар грисров. В 2008 г. грисы успешно размножаиись на двух соседних гнездах лево-

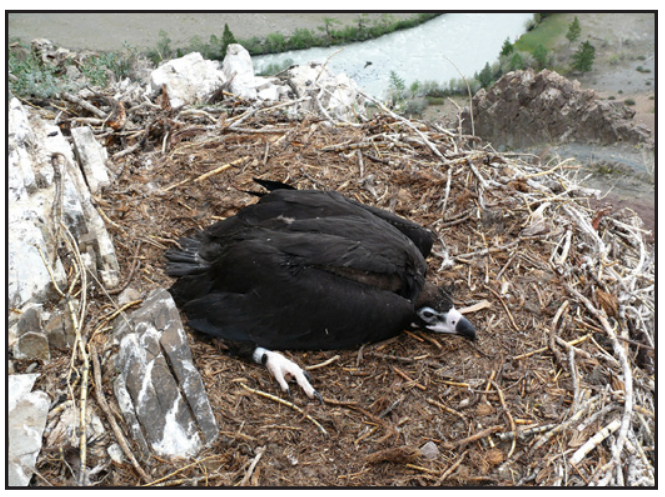

Птенец грисра (Aegypius monachus) в гнезце. ЧаганУзун. 21.07.2011. Фото Р. Бекмансурова.

Nestling of the Cinereous Vulture (Aegypius monachus) in the nest. Chagan-Uzun. 21/07/2011. Photo by R. Bekmansurov.

2011, 2013, 2014), Chagan-Uzun population bear 6 fledglings, which gave us breeding success equal to 0.5 fledgling per pair.

Today colony in Chagan-Uzun is the only known population of Cinereous Vulteres in Russian Altai. However, it is not ruled out that there are other colonies still unknown (fig.1). Taking into account regular observations of Cinereous Vultures in Chuya Steppe and even in Kuray Steppe we can assume the presence of another breeding populations in SouthEastern Altai.

We never recorded positive breeding outcome among Cinereous Vultures that bred out of colonies in Altai. But we did not exclude such possibility because in Tuva Republic there are several known cases of successful breeding in solitary pairs.

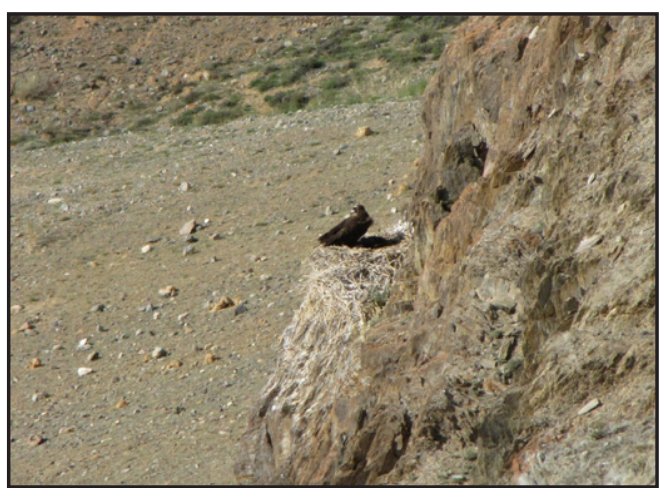

Грифы (взрослая птица и птенец) в гнезце. ЧаганУзун. 03.07.2013. Фото А. Барашковой.

Adult and nestling of the Cinereous Vulture in the nest. Chagan-Uzun. 03/07/2013. Photo by A. Barashkova. 
го борта ушелья, удалённых мруг от Аруга на 1,17 км. В 2011 г. вылупление птенцов также было зарегистрировано на $\Delta$ вух этих же гнёздах, но успешным оказалось мишь одно гнезАо, занимавшееся грисом с 2006 г. На втором гнезде уже оперяюшийся птенец был убит и съеден пернатым хишником, вероятно, беркутом, гнездяшимся в этом же ушелье в 900 м от гнезда грисра. Третья пара все эти годы абонировала две постройки, периодически подновляя одну из них, на противоположной стороне ушеАья, в 0,95 и 1,16 км от гнёзд грисов, размножавшихся на скаиах мевого борта ушеАья. При проверке 2013 г. именно эта пара гнездилась успешно, а две Аругие, размножавшиеся в 2008-2011 гг., абонироваии гнёзАа, возможно и пытаиись размножаться, но успешного размножения не произошло. Интересно отметить, что одна из Аолго живуших в этом ушелье пар, гнездование которой наблюдалось в одном и том же гнезде с 2006 г., построила новое гнездо в 290 м от старого, Аистанцировавшись от соседей на 1,45 и 1,37 км, соответственно. При обслеАовании ушелья в 2014 г. успешное размножение зарегистрировано на двух гнёздах грисов на левом борту ушелья.

Успех размножения грисров в ЧаганУзунской группировке за 4 года наблюАений (2008, 2011, 2013 и 2014 гг.) составия 0,5 птенца на пару (6 птенцов из возможных 12).

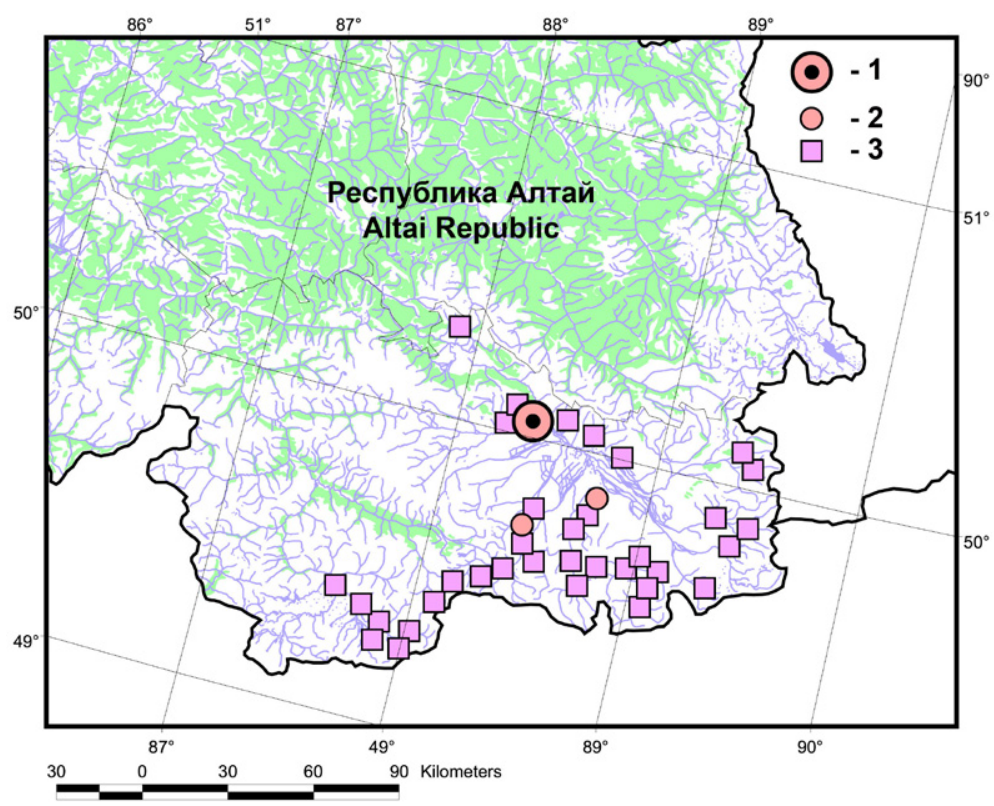

Рис. 1. Схема распространения грисра (Aegypius monachus) в Юго-Восточном Аитае: 1 - гнездовая группировка, 2 - попытки гнездования, 3 - места регулярных встреч птиц.

Fig. 1. Distribution of the Cinereous Vulture (Aegypius monachus) in the SouthEastern Altai: 1 - breeding group, 2 - nesting attempts, 3 - regular observations of the birds.

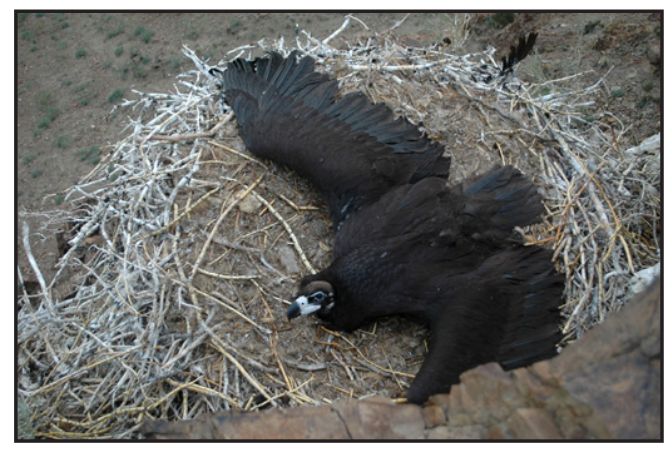

Птенец грифра в гнезде. Чаган-Узун. 23.07.2014. Фото И. Карякина.

Nestlings of the Cinereous Vulture in the nest Chagan-Uzun. 23/07/2014. Photo by I. Karyakin.

В настояшее время это единственная известная гнездовая группа грисов на Российском Алтае, но возможно не единственная сушествуюшая - см. рис. 1. Учитывая регулярные встречи грисров в течение всего гнездового периода по всей перисерии Чуйской степи и Ааже в Курайской степи, можно предполагать ешё намичие таких гнездовых групп на территории Юго-Восточного Алтая.

Нами так и не бы^о зарегистрировано успешного размножения грисов, пытавшихся размножаться одиночно вне групп. Но мы не искиючаем такой возможности, так как случаи успешного гнездования одиночных пар грисов вне гнездовых групп известны в Туве.

\section{Литература}

Аементьев Г.П. ОтряА хишные птицы. - Птицы Советского Союза. М.: Советская наука, 1951. T. 1. С.70-341.

Ирисова Н.А. Бородач. Чёрный гриср. Белоголовый сип. - Красная книга Республики Аитай: Животные. Новосибирск, 1996. С. 138-143.

Ирисова Н.А., Ирисов Э.А., Пятков К.М., Аукьянов Ю.П. О распространении на Алтае некоторых птиц, внесённых в Красную книгу РСФСР. - Редкие наземные позвоночные Сибири. Новосибирск, 1988. С. 94-97.

Карякин И.В., Коновалов А.И., Грабовский М.А., Николенко Э.Г. Пацаиьшики Аитае-Саянского региона. - Пернатые хишники и их охрана. 2009а. № 15. С. 37-65.

Карякин И.В., Николенко Э.Г., Важов С.В., Бекмансуров Р.Х. Новые Аанные о падальшиках Алтая, Россия. - Пернатые хишники и их охрана. 2009б. № 16. С. 173-176.

Нейфельдт И.А. Из результатов орнитологической экспедиции на Юго-Восточный Алтай. - Распространение и биология птиц Алтая и Аальнего Востока. А., 1986. С. 7-43.

Сушкин П.П. Птицы Советского Аитая и прилежаших частей Северо-Западной Монголии. M. - ^., 1938. T. 1.316 c., T. 2. 434 c. 